\title{
Analysis of up-to-date studies investigating effects of physical rehabilitation on traditional and novel biochemical parameters in PAD patients with intermittent claudication: a review
}

\author{
Katarzyna Skorkowska-Telichowska ${ }^{1,2}$, Urszula Pilch ${ }^{2,3}$, Andrzej Szuba ${ }^{1,2}$ \\ 'Department of Internal Medicine, $4^{\text {th }}$ Military Hospital in Wroclaw, Poland \\ ${ }^{2}$ Wrovasc - Integrated Medical Cardio-Vascular Centre, Regional Specialist Hospital in Wroclaw, Research and Development \\ Centre, Wroclaw, Poland \\ ${ }^{3}$ Department of Rehabilitation, School of Physical Education in Wroclaw, Poland
}

\begin{abstract}
Peripheral arterial disease severity ranges from asymptomatic (Fontaine stage I) through intermittent claudication (Fontaine stage II) to critical ischaemia (stage III and IV). Supervised exercise training is the main therapy used for PAD in the intermittent claudication stage.

The aim of this article is to review the current literature in order to highlight known factors of PAD pathophysiology that change significantly after long-term exercise training and to determine future predictors for the effectiveness of PAD claudicants rehabilitation treatment.

PubMed were searched for articles published during the last 23 years. The focus was on prospective randomized studies with control group, with long-term exercise training models that have met the EBM criteria.

Except for the combination of traditional, nonspecific atherosclerosis factors only: I) nitric oxide metabolite plasma concentrations as a marker of endothelial cell function, 2) plasma fibrinolysis activity and 3) obtained from gastrocnemius muscle biopsy markers of angiogenesis and myosin heavy chain (MHC) protein change significantly before and after physical rehabilitation in PAD patients with intermittent claudication.

There is limited data on the associations between atherosclerosis markers as predictors of exercise training effectiveness in peripheral atherosclerosis. The current review contributes to a better understanding of the mechanisms that lead to the improvement of the clinical status of patients with intermittent claudication in the course of long-term physical training.

Clearly, there is a need for further studies to understand the biochemical mechanisms involved in vascular changes due to physical rehabilitation.
\end{abstract}

Key words: atherosclerosis, claudicant, biochemical markers, inflammatory markers, exercise training, physical training, physical rehabilitation

Acta Angiol 2015; $21,2: 66-74$

Address for correspondence: Katarzyna Skorkowska-Telichowska, Department of Internal Medicine, $4^{\text {th }}$ Military Hospital,

R. Weigla 5, 50-98I Wroclaw, tel.: +48 7I 76606 67, fax: +48 7I 76605 99, e-mail: cathcor@poczta.onet.pl 


\section{Introduction}

Peripheral arterial disease (PAD) affects $12-14 \%$ of the general population and its prevalence increases with age, affecting up to $20 \%$ of patients over the age of 75 [I-4]. It is an independent risk factor for myocardial infarction and thrombotic events [5]. Overall, PAD is believed to affect approximately 27 million people in Europe and North America [6].

PAD is under-diagnosed and under-treated [6]. Early diagnosis and treatment are critical for slowing or impeding PAD progression.

Patients with PAD need individualized and complex therapy. Established strategies for PAD care include: reduction of atherosclerosis risk factors (Table I), pharmacology (vasoactive agents, rheology improvement agents) and invasive treatment in advanced stages (endovascular therapy - percutaneous transluminal angioplasty or surgical interventions such as endarterectomy and lower extremity revascularization) [ $I$, 7-9]. However, a key PAD treatment (used in stage II according to the Fontaine Classification, Table 2) which improves claudication distance is exercise training
$[10,11]$. Regular aerobic exercise, more than any pharmacological or surgical intervention, has been shown to be an effective treatment option regardless of other atherosclerotic risk factors [12, 13].

The results of the different supervised physical training patterns in the stage IIb PAD patient varied. Some individuals did not show any improvement in walking distance or only a slight improvement. Conversely, some of the subjects showed excellent results [19].

The mechanism, by which exercise contributes to the improvement of walking distance and consequently the patient's functional behaviour, remains speculative [20-25].

The aim of this article is to review the current literature and evaluate known factors of PAD pathophysiology that change significantly after a physical training program.

This would be useful as basic knowledge for developing a new study that will focus on finding a predictive tool which could indicate, before treatment, whether or not physical rehabilitation would be a more suitable approach for a Fontaine stage II PAD patient than a more invasive modality.

Table I. Known factors involved in PAD pathophysiology [14-17]

\begin{tabular}{|c|c|c|c|c|}
\hline \multicolumn{2}{|c|}{ Classical factors } & \multirow{2}{*}{\multicolumn{3}{|c|}{$\begin{array}{c}\text { Non-classical factors } \\
\text { Non-modifiable }\end{array}$}} \\
\hline \multirow[t]{2}{*}{ Modifiable } & \multirow[t]{2}{*}{ Non-modifiable } & & & \\
\hline & & Haemostatic factors & Inflammatory markers & Angiogenesis markers \\
\hline $\begin{array}{l}\text { Unhealthy dietary } \\
\text { patterns }\end{array}$ & Advanced age & Haematocrit & hs CRP & $\begin{array}{l}\text { Vascular endothelial } \\
\text { growth factor (VEGF) }\end{array}$ \\
\hline Tobacco smoking & Male gender & Platelet count & Homocysteine & sVEGFR-I (Flt-I) \\
\hline Lack of physical activity & $\begin{array}{l}\text { Close relatives } \\
\text { with atheroscle- } \\
\text { rosis complication }\end{array}$ & D-dimer & $\begin{array}{l}\text { Lipoprotein (a) } \\
\text { Ox-LDL }\end{array}$ & $\begin{array}{l}\text { sTie-2 } \\
\text { Angiopoietin } 2\end{array}$ \\
\hline Arterial hypertension & $\begin{array}{l}\text { Genetic abnorma- } \\
\text { lities, e.g. familial } \\
\text { hypercholestero- } \\
\text { laemia }\end{array}$ & $\begin{array}{l}\text { aPTT } \\
\text { Prothrombin time }\end{array}$ & $\begin{array}{l}\text { sE selectin } \\
\text { sVCAM-I } \\
\text { sICAM-I }\end{array}$ & $\begin{array}{l}\text { Hepatocyte growth } \\
\text { factor (HGF) }\end{array}$ \\
\hline Dyslipoproteinaemia & & $\begin{array}{l}\text { von Willebrand factor } \\
\text { VII factor }\end{array}$ & $\begin{array}{l}\text { Interleukin I, 6, 8, I8, } \\
\text { TNF-alpha, MCP-I } \\
\text { Endothelin-I }\end{array}$ & $\begin{array}{l}\text { Fibroblast growth } \\
\text { factor (FGF) }\end{array}$ \\
\hline $\begin{array}{l}\text { Diabetes or impaired } \\
\text { glucose tolerance }\end{array}$ & & Fibrinogen & $\begin{array}{l}\text { SAA (serum amyloid A } \\
\text { protein) }\end{array}$ & \\
\hline Visceral obesity & & $\begin{array}{l}\text { Plasminogen activator } \\
\text { inhibitor-I (PAl-I) }\end{array}$ & ADMA & \\
\hline \multirow[t]{2}{*}{ A sedentary lifestyle } & & $\begin{array}{l}\text { Tissue plasminogen } \\
\text { activator (t-PA) antigen }\end{array}$ & $\begin{array}{l}\text { Haptoglobin } \\
\text { Ceruloplazmin } \\
\text { Alpha2-macroglobulin } \\
\text { Beta2-microglobulin }\end{array}$ & \\
\hline & & $\begin{array}{l}\text { Tissue factor (TF) } \\
\text { Thrombomodulin } \\
\text { Thrombospondin-I }\end{array}$ & $\begin{array}{l}\text { Chronic systemic in- } \\
\text { fections: } \\
\text { C. pneumoniae, } \\
\text { H. pylori, CMV }\end{array}$ & \\
\hline
\end{tabular}


Table 2. Clinical classification for chronic ischaemia of lower extremities according to Leriche-Fontaine and Rutherford-Baker scales and $\mathrm{ABI}$ measurement [18]

\begin{tabular}{|c|c|c|c|}
\hline $\begin{array}{l}\text { Stage according } \\
\text { to Fontaine }(\mathrm{F})\end{array}$ & Clinical symptoms & $\begin{array}{l}\text { Ankle-brachial } \\
\text { index }(\mathrm{ABI})^{* * *}\end{array}$ & Class according to Rutherford-Baker (R-B) \\
\hline 1 & $\begin{array}{l}\text { Without symptoms or symptoms at } \\
\text { a very high level of activity }\end{array}$ & $<0.9$ & \multirow[t]{2}{*}{ I } \\
\hline lla* & $\begin{array}{l}\text { Claudication }>200 \mathrm{~m} \text {, symptoms at } \\
\text { moderate level of activity }\end{array}$ & $0.7-0.9$ & \\
\hline \multirow[t]{2}{*}{ llb* } & \multirow{2}{*}{$\begin{array}{l}\text { Claudication }<200 \mathrm{~m} \text {, symptoms at } \\
\text { a low level of activity }\end{array}$} & $0.5-0.69$ & II* \\
\hline & & $0.5-0.69$ & III* \\
\hline III & Leg pain at rest & $<0.5$ & IV \\
\hline \multirow[t]{2}{*}{ IV } & \multirow[t]{2}{*}{ Ulceration with tissue necrosis } & $<0.5$ & V (ulceration) \\
\hline & & $<0.5$ & VI (ulceration with tissue necrosis) \\
\hline
\end{tabular}

* Claudicants are considered in the R-B II-III class and F Ila, Ilb stage

**ABI is calculated by dividing the ankle pressure over the highest brachial pressure. Sensitivity of $A B I$ is $90 \%$ with a corresponding $98 \%$ specificity for detecting hemodynamically significant stenosis $>50 \%$ in major leg arteries, defined by an angiogram

The changes in biomarkers after longitudinal exercise training in PAD patients: is there any correlation with clinical improvement?

According to the current literature, an increase in coagulation and inflammatory potential during acute exercise among PAD patients compared to healthy individuals is well known [26-28].

A decrease in the level of the same pro-coagulatory and pro-inflammatory factors due to long-term physical rehabilitation has been noted during investigations. However, is there, among the well-known markers, an agent that can predict positive effects among PAD patients receiving supervised aerobic physical training?

The influence of supervised exercise on the inflammatory biochemical response at the cellular level could be recognized by measuring plasma markers. This could be done with classical indicators, such as a lipid profile, or with new ones, like soluble forms of intercellular adhesion molecules. Alternatively, endothelial function may be evaluated by measuring the NO-dependent vasodilator response.

Only limited data exists regarding comparisons between levels of atherosclerotic biomarkers before and after long-term exercise training.

\section{Traditional biochemical PAD factors}

There have been several studies (Table 3 ) that assess the effect of exercise on changes of well-known haemostatic factors: haematocrit, platelet count, white blood count, aPTT, prothrombin time, prothrombin I.2, D-dimer, t-PA, vWF, plasminogen, plasma fibrinogen, biochemical markers, like lipid profiles (total cholesterol, low density lipoprotein, high density lipoprotein, oxidized low density lipoprotein, triglycerides), and fasting glucose in patients with PAD stage II, according to the Fontaine Classification.

The studies vary because of diagnostic tools for ischaemia in the lower extremities, stage of ischaemia of the lower extremities, number of study patients, demographic data of the study group, type of training program performed, different endurance exercise protocols, related atherosclerosis risk factors and medication intake (lipid-lowering therapy, for example).

The cited works have shown that exercise improves haemorheology, facilitating oxygen delivery to ischaemic skeletal muscle. Moreover, other well-established risk factors like lipid profile and haemostatic factors, as well as less-established risk factors (blood rheology, hs-CRP, D-dimer) that can impact patients with PAD, can be improved by supervised training. But all of them are nonspecific.

\section{Novel inflammatory PAD risk factors}

There is a strong clinical need for more specific biomarkers for PAD recognition in its early stages and to reflect prognostic information of the prescribed therapy.

We searched PubMed for articles published during the last 23 years using the terms: exercise training, exercise program, rehabilitation, physical rehabilitation, treadmill training, aerobic training, physical activity combined with PAD, intermittent claudication, claudicants and haemostatic factors, inflammatory markers and cytokines, as well as all biochemical markers with 
Table 3. Selected randomized trials on changes of biochemical markers after long-term exercise training in symptomatic stage II $P A D$, according to the Leriche-Fontaine Scale [22, 29-45]

\begin{tabular}{|c|c|c|c|c|}
\hline $\begin{array}{l}\text { Author } \\
\text { Year } \\
\text { Journal }\end{array}$ & $\begin{array}{l}\text { No. of } \\
\text { patients }\end{array}$ & $\begin{array}{l}\text { Duration of } \\
\text { exercise } \\
\text { program }\end{array}$ & Method of rehabilitation & Results \\
\hline $\begin{array}{l}\text { Mika P et al. 20I I } \\
\text { Eur J Cardiovasc } \\
\text { Prev Rehabil. [29] }\end{array}$ & 68 & 3 months & $\begin{array}{l}\text { Pain-free treadmill } \\
\text { training }\end{array}$ & $\begin{array}{l}\downarrow \text { total cholesterol by } 14.8 \% \\
\downarrow \text { LDL-C } 20.5 \% \\
\uparrow \text { HDL-C } 14.6 \% \\
\downarrow \text { triglycerides } 19 \% \\
\leftrightarrow \mathrm{Ht} \text {, fibrinogen }\end{array}$ \\
\hline $\begin{array}{l}\text { Andreozzi GM et al. } \\
2007 \\
\text { Int Angiol. [30] }\end{array}$ & 22 & 6 weeks & Treadmill training & $\begin{array}{l}\uparrow E F \text { (endothelial function), assessed by } \\
\text { ultrasonography of the brachial artery. } \\
\text { Before training, the pre-exercise EF was } \\
7.6 \pm 2.94 \text { and post-exercise EF } 5.28 \pm 3.3 \\
(-33.2 \%)(p<0.01) \\
\text { After training, the pre-exercise EF was } \\
10.3 \pm 4.04 \text { and post-exercise EF was } \\
7.79 \pm 2.56(-18.97 \%)(p<0.01)\end{array}$ \\
\hline $\begin{array}{l}\text { Sillesen } \mathrm{H} \text { et al. } 2007 \\
\text { Eur J Vasc Endovasc } \\
\text { Surg. [3I] }\end{array}$ & 693 & $\begin{array}{l}4 \text { year } \\
\text { period of } \\
\text { observa- } \\
\text { tion }\end{array}$ & $\begin{array}{l}\text { Nurse-driven rehabi- } \\
\text { litation }\end{array}$ & $\begin{array}{l}\downarrow \text { mean total cholesterol from } 6.2 \mathrm{mmol} / \mathrm{L} \\
\text { to } 4.9 \mathrm{mmol} / \mathrm{L} \\
\downarrow \text { mean } \mathrm{LDL}-C \text { from } 3.9 \mathrm{mmol} / \mathrm{L} \text { to } 2.6 \\
\mathrm{mmol} / \mathrm{L}\end{array}$ \\
\hline $\begin{array}{l}\text { Mika P et al. } 2006 \\
\text { Clin J Sport Med. } \\
{[32]}\end{array}$ & 60 & 3 months & $\begin{array}{l}\text { Pain free treadmill } \\
\text { training }\end{array}$ & $\begin{array}{l}\uparrow \text { increasing erythrocyte deformability } \\
(p<0.0 \mathrm{I})\end{array}$ \\
\hline $\begin{array}{l}\text { Huffman K. et al. } \\
2006 \text { Am Heart J } \\
{[33]}\end{array}$ & 193 & 6 months & $\begin{array}{l}\text { Aerobic exercise } \\
\text { groups }\end{array}$ & $\leftrightarrow \mathrm{hsCRP}$ \\
\hline $\begin{array}{l}\text { Mika P et al. } 2005 \\
\text { Am J Phys Med } \\
\text { Rehabil. [34] }\end{array}$ & 98 & 12 weeks & $\begin{array}{l}\text { Supervised treadmill } \\
\text { training }\end{array}$ & $\begin{array}{l}\leftrightarrow \text { total leukocyte count } \\
\leftrightarrow \text { neutrophil count } \\
\leftrightarrow \text { microalbuminuria }\end{array}$ \\
\hline $\begin{array}{l}\text { McDermott MM } \\
\text { et al. 2004 } \\
\text { J Cardiopulm } \\
\text { Rehabil. [35] }\end{array}$ & $\begin{array}{l}32 \text { PAD; no } \\
\text { symptoms of } \\
\text { claudication }\end{array}$ & 12 weeks & Exercise training & $\begin{array}{l}\text { There were no significant changes in } \\
\text { inflammatory blood factors after exercise }\end{array}$ \\
\hline $\begin{array}{l}\text { McDermott MM } \\
\text { et al. } 2004 \\
\text { Vasc Med. [36] }\end{array}$ & 188 & 7 days & $\begin{array}{l}\text { Physical activity } \\
\text { during daily life }\end{array}$ & $\begin{array}{l}\downarrow \text { D-dimer } \\
\leftrightarrow \text { CRP, } \leftrightarrow \text { fibrinogen } \\
\leftrightarrow \text { serum amyloid A (SAA) } \\
\leftrightarrow \text { prothrombin I.2 } \\
\leftrightarrow \text { t-PA antigen, PAI-I }\end{array}$ \\
\hline $\begin{array}{l}\text { Turton EP et al. } \\
2002 \\
\text { Eur J Vasc Endovasc } \\
\text { Surg. [37] }\end{array}$ & 46 & 3 month & $\begin{array}{l}\text { Supervised exercise- } \\
\text {-training program } \\
\text { (treadmill exercise) }\end{array}$ & $\begin{array}{l}\downarrow \text { neutrophil activation } \\
\downarrow \text { neutrophil degranulation } \\
\downarrow \text { free radical damage }\end{array}$ \\
\hline $\begin{array}{l}\text { Izquierdo-Porrera } \\
\text { AM et al. } 2000 \\
\text { J Vasc Surg [38] }\end{array}$ & 34 & 6 months & Treadmill training & $\begin{array}{l}\downarrow \text { total cholesterol by } 5.2 \%(\mathrm{p}<0.00 \mathrm{I}) \\
\downarrow \text { LDL-C } 8 \%(\mathrm{p}<0.05) \\
\leftrightarrow \text { fasting glucose } \\
\leftrightarrow \text { triglycerides } \\
\leftrightarrow \text { HDL-C }\end{array}$ \\
\hline $\begin{array}{l}\text { Tan KH et al. } 2000 \\
\text { Eur J Vasc Endovasc } \\
\text { Surg. [39] }\end{array}$ & 40 & 3 months & Exercise training & $\begin{array}{l}\uparrow \text { HDL-C } \\
\leftrightarrow \text { rheology, lipid profile except HDL-C } \\
\downarrow \text { lactate levels }\end{array}$ \\
\hline $\begin{array}{l}\text { Ramírez-Tortosa MC } \\
\text { et al. } 1999 \\
\text { Clin Nutr [40] }\end{array}$ & 13 & 15 months & Treadmill training & $\begin{array}{l}\downarrow \text { triglycerides } \\
\uparrow \mathrm{HDL}-\mathrm{C} \\
\leftrightarrow \mathrm{LDL}-\mathrm{C}\end{array}$ \\
\hline
\end{tabular}


Table 3. (cont.) Selected randomized trials on changes of biochemical markers after long-term exercise training in symptomatic stage II PAD, according to the Leriche-Fontaine Scale [22, 29-45]

\begin{tabular}{|c|c|c|c|c|}
\hline $\begin{array}{l}\text { Author } \\
\text { Year } \\
\text { Journal }\end{array}$ & $\begin{array}{l}\text { No. of } \\
\text { patients }\end{array}$ & $\begin{array}{l}\text { Duration of } \\
\text { exercise } \\
\text { program }\end{array}$ & Method of rehabilitation & Results \\
\hline $\begin{array}{l}\text { Capecchi PL et al. } \\
1997 \\
\text { Angiology [22] }\end{array}$ & 14 & $\begin{array}{l}\text { Five repe- } \\
\text { ated sub- } \\
\text { maximal } \\
\text { exercises } \\
\text { at five-mi- } \\
\text { nute and } \\
\text { two-hour } \\
\text { intervals }\end{array}$ & Treadmill training & $\begin{array}{l}\uparrow \text { an improvement in blood rheology } \\
\downarrow \text { PMN } \\
\downarrow \text { plasma levels of adenosine and ATP }\end{array}$ \\
\hline $\begin{array}{l}\text { Tisi PV et al. } 1997 \\
\text { Eur J Vasc Endovasc } \\
\text { Surg. [4I] }\end{array}$ & 67 & 3 months & $\begin{array}{l}\text { Supervised exercise } \\
\text { training }\end{array}$ & $\begin{array}{l}\uparrow \text { urinary ACR (albumin-creatinine ratio) } \\
\leftrightarrow \text { fibrinogen } \\
\downarrow \text { SAA (serum amyloid A protein) } \\
\downarrow \text { CRP }\end{array}$ \\
\hline $\begin{array}{l}\text { Hiatt WR et al. } \\
1996 \\
\text { J Appl Physiol. [42] }\end{array}$ & 26 & 12 weeks & $\begin{array}{l}\text { Walking vs. strength } \\
\text { training } \\
\text { Treadmill training }\end{array}$ & $\begin{array}{l}\text { Improvement in exercise performance with } \\
\text { treadmill training was associated with a cor- } \\
\text { relative decrease in the plasma ( } r=-0.67) \\
\text { and muscle }(r=-0.59) \text { short-chain acylcarni- } \\
\text { tine concentrations }\end{array}$ \\
\hline $\begin{array}{l}\text { Pancera P et al. } 1995 \\
\text { Scand J Rehabil Med. } \\
\text { [43] }\end{array}$ & 15 & I month & $\begin{array}{l}\text { Physical activity } \\
\text { during daily life }\end{array}$ & $\begin{array}{l}\downarrow \text { white blood cell count, triglycerides, } \\
\text { uric acid } \\
\leftrightarrow \text { prothrombin time, aPTT, plasminogen, } \\
\text { platelet count } \\
\uparrow \text { fibrinogen }\end{array}$ \\
\hline $\begin{array}{l}\text { Binaghi F et al. } 1990 \\
\text { Int Angiol. [44] }\end{array}$ & 26 & 3 months & $\begin{array}{l}\text { Patients were instru- } \\
\text { cted to walk for } \\
\text { a minimum period } \\
\text { of I hour daily }\end{array}$ & $\begin{array}{l}\leftrightarrow \mathrm{Ht} \\
\leftrightarrow \text { total cholesterol } \\
\downarrow \text { fibrinogen }\end{array}$ \\
\hline $\begin{array}{l}\text { Hiatt WR et al. } 1990 \\
\text { Circulation [45] }\end{array}$ & 19 & 12 weeks & $\begin{array}{l}\text { Supervised treadmill } \\
\text { training }\end{array}$ & $\begin{array}{l}\downarrow 26 \% \text { decrease in resting plasma short-chain } \\
\text { acylcarnitine concentration }(p<0.05)\end{array}$ \\
\hline
\end{tabular}

$\mathrm{Ht}$ — haematocrit, hsCRP — high sensitivity C-reactive protein, EF — endothelial function, PMN — polymorphonuclear leukocytes, $\uparrow$ increase, $\downarrow$ decrease, $\leftrightarrow$ no significant changes

documented engagement in PAD pathophysiology. The focus was on prospective randomized controlled trials of more than 40 participants, with long-term exercise training models ( $>3$ months) that have met the EBM criteria. Only a few articles fulfilled these criteria.

\section{Markers of endothelial cell function}

In one study, "plasma nitrate flux" (total nitric oxide metabolite concentration) and brachial artery flow-mediated dilatation as an endothelial function barometer allowing vasodilation were examined. The authors examined PAD subjects before and after 3 months (3 times per week) of supervised or home exercise training. At the baseline visit, there were no differences in the resting plasma nitrite values between the examined groups. At 3 months, the peripheral arterial disease-supervised group showed increases in: brachial artery flow-mediated dilation, a significant plasma nitrate flux, time to onset of claudication pain, peak walking time and $\mathrm{VO}_{2}$ Peak. There were no changes in the peripheral arterial disease home group. The change in plasma nitrite flux predicted the change in onset of claudication pain [46].

\section{Inflammatory markers}

The effects of the 24-week exercise program on levels of circulating biomarkers of atherosclerosis (sVCAM-I, sICAM-I, sE-selectin, high sensitivity C-reactive protein [hs-CRP]) and stress proteins ( $\mathrm{Hsp} 60$ and $\mathrm{Hsp} 70$ ) in PAD patients with Fontaine stage II were investigated. Patients were randomized to groups of arm or leg cranking exercises and compared with the controls. Investigators found no effect of exercise on circulating levels of soluble adhesion molecules or stress proteins after rehabilitation. They did notice that improvements 
in training limb-specific oxygen consumption were not as great for patients in the highest quartile for circulating sVCAM-I baseline levels as they were in patients in the lowest quartile at baseline. The authors concluded that high levels of circulating sVCAM-I are associated with an attenuated exercise response and that training may provide an effective stimulus for evoking systemic anti-inflammatory adaptations in patients with intermittent claudication [47].

In another study, the authors assessed the effect of an 8-week supervised training program on endothelium-derived inflammatory markers: adhesion molecule plasma levels (E-selectin, ICAM- I, VCAM-I) in 29 PAD patients. The authors noticed a significant reduction in E-selectin and ICAM-I plasma levels with an unchanged VCAM-I level after the program [48].

The study evaluated the associations of physical activity during daily life with levels of C-reactive protein, interleukin-6, soluble intracellular adhesion molecule- I, soluble vascular cellular adhesion molecule- I, D-dimer and homocysteine in 244 PAD patients. Physical activity was objectively assessed with a vertical accelerometer, which participants wore continuously for 7 days. In conclusion, more intensive physical activity was associated with lower levels of inflammatory markers, homocysteine and D-dimer after the experiments [49].

\section{Markers of angiogenesis}

The expressions of inflammatory markers, such as vWF, II-6, TNF-alpha and hs-CRP, and of vascular growth factors (VEGF and FGF-2) were investigated before and at four points after the treadmill test in I9 PAD patients. The levels of examined markers were obtained in a gastrocnemius muscle biopsy (mRNA growth factors) (10 patients). Cytokines and growth factor concentrations were measured in plasma. Five patients who did not experience pain during the marching test were treated as a control group. The results showed statistically significant elevated II-6 plasma levels and a decrease in FGF-2 plasma levels with no changes in other biological markers. Biopsies revealed an increase of VEGF mRNA in patients who experienced exercise-induced pain. The authors' conclusion was that it is plausible that a satisfactory exercise effect in the examined patients was due to angiogenesis stimulation. Markers of angiogenesis could be used as a potential tool for predicting exercise effects [50].

Another study explored muscle concentration of pro-angiogenic VEGF-A, VEGF receptor I and VEGF (I65)b with anti-angiogenic properties in PAD patients compared with the control group. Before and after 36 sessions (three times a week) of supervised exercise training (SET) or home exercise training, both PAD groups and healthy controls underwent a gastrocne- mius muscle biopsy. At baseline, three groups had similar concentrations of VEGF-A, and the VEGF RI concentration was lower in PAD patients compared with the controls. Rehabilitation was associated with a significant reduction in the skeletal VEGF-A level and a trend toward increased VEGF(165)b levels with no changes in VEGF-RI levels between the two PAD groups. There was a significant positive relationship between skeletal muscle VEGF-A concentrations and the number of capillaries per fibre and capillaries per $\mathrm{mm}^{2}$ in PAD patients after 12 weeks of SET. The finding that VEGF-A did not increase and/or that the inhibitory form of $V_{E G F_{165}} b$ failed to decrease following exercise training, despite an increase in the number of capillaries, was quite unexpected [5I].

Two controlled trial studies arranged by the same group of investigators explored the impact of a six-month supervised treadmill program on markers of angiogenesis and endothelial function in 40 PAD patients (first study) [52]. Serum markers of inflammation and platelet activation related to cardiovascular risk were determined in 53 PAD patients with intermittent claudication (second study) [53]. Patients were randomized into two groups: supervised treadmill training with best medical practice vs. best medical practice. In both works, endothelial progenitor cells (EPC) were measured by flow cytometry and cell culture assays (endothelial cell-colony forming units, circulating angiogenic cells, migration assay), changes of the plasma levels of ADMA and VEGF were estimated. The stromal cell-derived factor-I (SDF-I) was determined at baseline and at 3, 6 and 12 months after inclusion. EPC in both examined methods increased significantly upon training in parallel with a significant decrease of ADMA when compared to the control group. Six months after training cessation, the beneficial effect of supervised treadmill training on EPC diminished, but maximum walking distance was significantly improved compared to baseline and controls. No significant changes were observed for VEGF and SDF-I plasma levels.

Supervised treadmill training increases circulating EPC counts and produces decreases in ADMA levels, reflecting enhanced angiogenesis and improved endothelial function, which might contribute to cardiovascular risk reduction [52]. In the second work, high sensitivity C-reactive protein (hs-CRP), interleukin-6 (IL-6), fibrinogen, soluble P-selectin, prothrombin fragment I +2 (FI.2) and monocyte-platelet aggregates (MPA) were determined at study entry and after 3, 6 and 12 months. While clinical improvement, reflected by an increase in walking capacity, was observed upon supervised treadmill training, no lasting changes of markers of inflammation and platelet activation were found within the supervised treadmill-training group 
during the training period. Compared to the best medical practice group, no improvements of these markers were observed in response to training at any point in time. The authors came to the conclusion that regular supervised treadmill training added no further anti-inflammatory effect and had no effect on platelet activation when provided in addition to best medical practice in PAD patients with intermittent claudication [53].

\section{Markers of fibrinolysis}

The effects of a 6-month treadmill program on fibrinolysis were tested in subjects with PAD. A trial group of 4 I men with intermittent claudication was randomized into a 6-month treadmill program $(n=21)$ or "usual care" $(n=20)$. Fibrinolytic activity was measured prior to and upon completion of the study. Fibrinolysis was quantified by measurement of the activity levels of tPA and its inhibitor PAI-I. Fibrinolysis, quantified as increased PAI-I activity, was reduced in both groups relative to healthy controls at baseline. After 6 months of exercise, the subjects in the training group experienced significant improvements in fibrinolytic activity, manifested as a decrease in PAI-I activity and an increase in tPA activity. No changes occurred in the traditionally treated group. In the training group, subjects with the highest initial PAI-I values experienced the greatest decreases in PAI-I activity [54].

\section{Markers of muscles' condition}

The next study sought evidence of differential myosin heavy chain (MHC) protein expression following supervised exercise for claudication. There is evidence that the improvement following supervised exercise for claudication resulted from skeletal muscle adaptation. The MHC determines muscle fibre type and, therefore, efficiency. Immunohistochemical analysis has failed to take into account hybrid MHC expression within myofibres. Thirty-eight claudicant patients were recruited. Subjects undertook a three-month supervised exercise program. The controls were patients awaiting angioplasty for claudication. Subjects underwent a paired gastrocnemius biopsy. Relative expression of $\mathrm{MHC}$ proteins was determined by electrophoresis. Upon completion of the exercise program, there was a $94 \%$ increase in maximum walking distance, which was not evident in the control group. An II.1\% (statistically significant) increase in $\mathrm{MHCl}$ expression was observed in the exercise group compared with the control group. There was a positive correlation between the change in $\mathrm{MHCl}$ expression and improvement in claudication distance. In conclusion, supervised exercise training for claudication results in an increase in the proportion of MHC type I expression within the symptomatic gastrocnemius muscle [55].

\section{miRNAs changes}

A tool that could serve as a new biomarker-predictor of rehabilitation in PAD patients is the use of microRNAs, due to their plasma detection. The microRNAs (miRNAs) are small non-coding RNAs involved in post-transcriptional gene regulation. They are taken in by intracellular exosomes, secreted into the circulatory system and taken up by other cells, where they regulate cellular functions. The authors hypothesized that muscle-enriched miRNAs existing in the circulatory system mediate beneficial metabolic responses induced by exercise training $[56,57]$. One group tested the impact of three-month treadmill training and single treadmill exercise on antioxidant gene expressions, cytokine concentrations, a number of marrow-derived pro-angiogenic progenitor cells (PPC) and miRNAs in the blood of claudicants. Blood samples of 12 patients were collected before and after training. Treadmill training improved pain-free walking time and maximum walking time in patients. After training program, the number of circulating PPCs remained stable, as well as miRNAs: miRNA- I55, - I46a, -200c, sVCAM-I, sICAM-I, adiponectin, II- I beta, -8, - I0, - I2, - I7, VEGF, FGF-2, INF-gamma. After training program plasma concentration of II-6, E-selectin, the tumour necrosis factor- $\alpha$ and PAI-I decreased, plasma level of MCP-I (monocyte chemoatractant associated with PAD that could be involved in angiogenesis) increased [58].

\section{Conclusions}

There is limited data on the associations between atherosclerosis markers as predictors of exercise training effectiveness in peripheral atherosclerosis.

According to up-to-date literature, except for the combination of traditional, nonspecific atherosclerosis factors, novel markers of exercise effectiveness may include: I. nitric oxide metabolite plasma concentrations as a marker of endothelial cell function,

2. plasma fibrinolysis activity and

3. obtained from gastrocnemius muscle biopsy markers of angiogenesis and myosin heavy chain (MHC) protein could serve as predictors of exercise training effectiveness for PAD claudicants.

Clearly, there is a need for further studies to understand the biochemical mechanisms involved in vascular changes due to physical rehabilitation. The clinical implications of these future findings will be extremely important.

\section{Acknowledgment}

This publication is part of Project "WroVasc — Integrated Cardiovascular Centre", co-financed by the 
European Regional Development Fund, within the Innovative Economy Operational Program 2007-2013, implemented in the Regional Specialist Hospital, Research and Development Centre in Wroclaw. "European Funds - for the development of innovative economy".

\section{References}

I. Milani RV, Lavie CJ (2007) The role of exercise training in peripheral arterial disease. Vasc Med; 12: 35I-358.

2. Selvin E, States TP (2004) Results from the National Health and Nutrition Examination Survey. Prevalence of and risk factors for peripheral arterial disease in the United States 1999-2000. Circulation; I 10: 738-743.

3. Shammas NW (2007) Epidemiology, classification, and modifiable risk factors of peripheral arterial disease. Vasc Health Risk Manag; 3: 229-234.

4. Chinsomboona J, Ruasb J, Rana K et al (2009) The transcriptional coactivator PGC-I mediates exercise-induced angiogenesis in skeletal muscles. PNAS; 106: 2140I-21406.

5. Silvestro A, Scopacasa F, Ruocco A (2003) Inflammatory status and endothelial function in asymptomatic and symptomatic peripheral arterial disease. Vasc Med; 8: 225-232.

6. Hiatt WR (200I) Medical treatment of peripheral arterial disease and claudication. N Engl J Med; 344: 1608-1621.

7. Rice TW, Lumsden AB (2006) Optimal medical management of peripheral arterial disease. Vasc Endovascular Surg; 40: 312-327.

8. Kügler CF, Rudofsky G (2003) The challenges of treating peripheral arterial disease. Vasc Med; 8: 109-1 14.

9. Mangiafico RA, Fiore CE (2009) Current management of intermittent claudication: the role of pharmacological and non-pharmacological symptom-directed therapies. Curr Vasc Pharmacol; 7: 394-4I3.

10. Watson L, Ellis B, Leng GC (2008) Exercise for intermittent claudication. Cochrane Database Syst Rev; 8: CD 000990.

II. Casillas JM, Troisgros O, Hannequin A et al (201 I) Rehabilitation in patients with peripheral arterial disease. Ann Phys Rehabil Med; 54: 443-46I.

12. Leone A, Laudani R, Definite G (2009) Unbalanced risk factors could compromise the effectiveness of physical training in patients with intermittent claudication? Minerva Cardioangiol; 57: 165-174.

13. Keo H, Grob E, Guggisberg F et al (2008) Long-term effects of supervised exercise training on walking capacity and quality of life in patients with intermittent claudication. Vasa; 37: 250-256.

14. Clark LT (2002) Vascular inflammation as a therapeutic target for prevention of cardiovascular disease. Curr Atheroscler Rep; 4: 77-81.

15. Kaplan RC, Frishman WH (200I) Systemic inflammation as a cardiovascular disease risk factor and as a potential target for drug therapy. Heart Dis; 3: 326-332.

16. Libby P, Ridker PM, Maseri A (2002) Inflammation and atherosclerosis. Circulation; 105: I I35-I I43.

17. Kannel WB (2005) Overview of haemostatic factors involved in atherosclerotic cardiovascular disease. Lipids; 40: 1215-1220.

18. Al-Qaisi M, Nott DM, King DH et al (2009) Ankle brachial pressure index (ABPI): an update for practitioners. Vasc Health Risk Manag; 5: 833-84I.
19. Sugimoto I, Ohta T, Ishibashi $\mathrm{H}$ et al (2010) Conservative treatment for patients with intermittent claudication. Int Angiol; 29 (Suppl): 55-60.

20. Parmenter BJ, Raymond J, Fiatarone S (2010) The effect of exercise on haemodynamics in intermittent claudication: a systematic review of randomised controlled trials. Sports Med; 40 : 433-447.

21. Wang J, Zhou S, Bronks R et al (2009) Effects of supervised treadmill walking training on calf muscle capillarisation in patients with intermittent claudication. Angiology; 60: 36-4I.

22. Capecchi PL, Pasini FL, Cati G (1997) Experimental model of short-time, exercise-induced preconditioning in POAD patients. Angiology; 48: 469-480.

23. Duscha BD, Robbins JL, Jones WS et al (201I) Angiogenesis in skeletal muscle precede improvements in peak oxygen uptake in peripheral artery disease patients. Arterioscler Thromb Vasc Biol; 31: 2742-2748.

24. Gardner AW, Katzel LI, Sorkin JD et al (2002) Effects of long-term exercise rehabilitation on claudication distances in patients with peripheral arterial disease: a randomised controlled trial. J Cardiopulm Rehabil; 22: 192-198.

25. Stewart AH, Smith FC, Baird RN et al (2008) Local versus systemic mechanisms underlying supervised exercise training for intermittent claudication. Vasc Endovascular Surg; 42: 314-320.

26. Brendle DC, Joseph LJO, Corretti MC et al (200I) Effects of exercise rehabilitation on endothelial reactivity in older patients with peripheral arterial disease. Am J Cardiol; 87: 324-329.

27. Payvandi L, Dyer A, McPherson D et al (2009) Physical activity during daily life and brachial artery flow-mediated dilation in peripheral arterial disease. Vasc Med; 14: 193-201.

28. Saetre T, Enoksen E, Lyberg $T$ et al (20I I) Supervised exercise training reduces plasma levels of the endothelial inflammatory markers E-selectin and ICAM-I in patients with peripheral arterial disease. Angiology; 62: 30I-305.

29. Mika P, Wilk B, Mika A et al (20II) The effect of pain-free treadmill training on fibrinogen, haematocrit and lipid profile in patients with claudication. Eur J Cardiovasc Prev Rehabil; 18: 754-760.

30. Andreozzi GM, Leone A, Laudani R et al (2007) Acute impairment of the endothelial function by maximal treadmill exercise in patients with intermittent claudication, and its improvement after supervised physical training. Int Angiol; 26: 12-17.

31. Sillesen $\mathrm{H}$, Madelung $\mathrm{S}$, Eldrup $\mathrm{N}$ et al (2007) Organising a nurse-driven PAD rehabilitation clinic within the vascular surgical department: what is required and are treatment goals reached? A prospective study. Eur J Vasc Endovasc Surg; 33: 26-32.

32. Mika P, Spodaryk K, Cencora A et al (2006) Red blood cell deformability in patients with claudication after pain-free treadmill training. Clin J Sport Med; 16: 335-340.

33. Huffman KM, Samsa GP, Slentz CA et al (2006) Response of high-sensitivity $\mathrm{C}$-reactive protein to exercise training in an at-risk population. Am Heart J; I52: 793-800.

34. Mika P, Spodaryk K, Cencora A et al (2005) Experimental model of pain-free treadmill training in patients with claudication. Am J Phys Med Rehabil; 84: 756-762.

35. McDermott MM, Tiukinhoy S, Greenland P et al (2004) A pilot exercise intervention to improve lower extremity functioning 
in peripheral arterial disease unaccompanied by intermittent claudication. J Cardiopulm Rehabil; 24: 187-196.

36. McDermott MM, Greenland P, Guralnik JM et al (2004) Inflammatory markers, D-dimer, pro-thrombotic factors and physical activity levels in patients with peripheral arterial disease. Vasc Med; 9: 107-II5.

37. Turton EP, Coughlin PA, Kester RC et al (2002) Exercise training reduces the acute inflammatory response associated with claudication. Eur J Vasc Endovasc Surg; 23: 309-316.

38. Izquierdo-Porrera AM, Gardner AW, Powell CC et al (2000) Effects of exercise rehabilitation on cardiovascular risk factors in older patients with peripheral arterial occlusive disease. J Vasc Surg; 31: 670-677.

39. Tan $\mathrm{KH}$, Cotterrell $\mathrm{D}$, Sykes $\mathrm{K}$ et al (2000) Exercise training for claudicants: changes in blood flow, cardiorespiratory status, metabolic functions, blood rheology and lipid profile. Eur J Vasc Endovasc Surg; 20: 72-78.

40. Ramírez-Tortosa MC, Urbano G, López-Jurado M et al (1999) Lifestyle changes in free-living patients with peripheral vascular disease (Fontaine Stage II) related to plasma and LDL lipid composition: a 15 month follow-up study. Clin Nutr; 18: 28I-289.

4I. Tisi PV, Hulse M, Chulakadabba A et al (1997) Exercise training for intermittent claudication: does it adversely affect biochemical markers of the exercise-induced inflammatory response? Eur J Vasc Endovasc Surg; 14: 344-350.

42. Hiatt WR, Regensteiner JG, Wolfel EE et al (1996) Effect of exercise training on skeletal muscle histology and metabolism in peripheral arterial disease. J Appl Physiol; 81: 780-788.

43. Pancera P, Prior M, Zannoni M et al (1995) Micro- and macro-circulatory and biohumoral changes after a month of physical exercise in patients with intermittent claudication. Scand J Rehabil Med; 27: 73-76.

44. Binaghi F, Fronteddu PF, Carboni MR et al (1990) Evaluation of non-invasive haemodynamic parameters in patients with intermittent claudication subjected to physical training. Int Angiol; 9: $25 \mathrm{I}-255$.

45. Hiatt WR, Regensteiner JG, Hargarten ME et al (1990) Benefit of exercise conditioning for patients with peripheral arterial disease. Circulation; 81: 602-609.

46. Allen J, Stabler T, Kenjale A et al (2010) Plasma nitrite flux predicts exercise performance in peripheral arterial disease after 3 months of exercise training. Free Radical Biology and Medicine; 15: II38-II44.
47. Saxton JM, Zwierska I, Hopkinson K et al (2008) Effect of upperand lower-limb exercise training on circulating soluble adhesion molecules, hs-CRP and stress proteins in patients with intermittent claudication. Eur J Vasc Endovasc Surg; 35: 607-613.

48. Saetre T, Enoksen E, Lyberg $T$ et al (201 I) Supervised exercise training reduces plasma levels of the endothelial inflammatory markers E-selectin and ICAM-I in patients with peripheral arterial disease. Angiology; 62: 30I-305.

49. Craft LL, Guralnik JM, Ferrucci L et al (2008) Physical activity during daily life and circulating biomarker levels in patients with peripheral arterial disease. Am J Cardiol; 102: 1263-1268.

50. Palmer-Kazen U, Religa P, Wahlberg E (2009) Exercise in patients with intermittent claudication elicits signs of inflammation and angiogenesis. Eur J Vasc Endovasc Surg; 38: 689-696.

5I. Jones WS, Duscha BD, Robbins JL et al (2012) Alteration in angiogenic and anti-angiogenic forms of vascular endothelial growth factor-a in the skeletal muscle of patients with intermittent claudication following exercise training. Vasc Med; 17: 94- 100.

52. Schlager $O$, Giurgea A, Schuhfried $O$ et al (20II) Exercise training increases endothelial progenitor cells and decreases asymmetric dimethylarginine in peripheral arterial disease: a randomised controlled trial. Atherosclerosis; 217: 240-248.

53. Schlager O, Hammer A, Giurgea A et al (20/2) Impact of exercise training on inflammation and platelet activation in patients with intermittent claudication. Swiss Med Wkly; I4: I42-I53.

54. Killewich LA, Macko RF, Montgomery PS et al (2004) Exercise training enhances endogenous fibrinolysis in peripheral arterial disease. Vasc Surg; 40: 74I-745.

55. Beckitt TA, Day J, Morgan M, Lamont PM (2012) Skeletal muscle adaptation in response to supervised exercise training for intermittent claudication. Eur J Vasc Endovasc Surg; 44: 313-317.

56. Aoi W, Ichikawa H, Mune $\mathrm{K}$ et al (2013) Muscle-enriched microRNA miR-486 decreases in circulation in response to exercise in young men. Front Physiol; II: 80.

57. Uhlemann M, Möbius-Winkler S, Fikenzer S (2014) Circulating microRNA-1 26 increases after different forms of endurance exercise in healthy adults. Eur J Prev Cardiol; 21: 484-49I.

58. Nowak WN, Mika P et al (20I2) Exercise training in intermittent claudication: effects on antioxidant genes, inflammatory mediators and pro-angiogenic progenitor cells. The role of microRNA in PAD patients as predictors of rehabilitation remains a melody of the future. Thromb Haemost; 108: 824-831. 